\title{
FOUCAULT, GARY BECKER AND THE CRITIQUE OF NEOLIBERALISM
}

\author{
- David Newheiser -
}

\begin{abstract}
Although Foucault's 1979 lectures on The Birth of Biopolitics promised to treat the theme of biopolitics, the course deals at length with neoliberalism while mentioning biopolitics hardly at all. Some scholars account for this elision by claiming that Foucault sympathized with neoliberalism; I argue on the contrary that Foucault develops a penetrating critique of the neoliberal claim to preserve individual liberty. Following Foucault, I show that the Chicago economist Gary Becker exemplifies what Foucault describes elsewhere as biopolitics: a form of power applied to the behavior of a population through the normalizing use of statistics. Although Becker's preference for indirect intervention might seem to preserve the independence of individuals, under biopolitics individual liberty is itself the means by which populations are governed indirectly. In my view, by describing the history and ambivalence of neoliberal biopolitics, Foucault fosters a critical vigilance that is the precondition for creative political resistance.
\end{abstract}

\section{Keywords}

biopolitics, neoliberalism, Foucault, critique, economics, power, normalization

According to the custom at the Collège de France, Michel Foucault named his 1978-79 lectures before they commenced, and the name he gave - The Birth of Biopolitics - corresponds to his intention to 'do a course on biopolitics this year' (Foucault, 2004: 23). Foucault planned to extend his trajectory at the time, which shifts from the analysis of disciplinary power in Discipline and Punish (1975) to consider the insidious power over life described in the first volume of The History of Sexuality (1976). However, it is not clear whether the lectures Foucault produced are about biopolitics after all; midway through he is forced to explain, 'Despite everything, I certainly intended at the outset to speak to you about biopolitics and yet, things being such as they are, you see that I have spoken at length (perhaps too long) about neoliberalism' (2004: 190). ${ }^{1}$ Apart from this apology, the term 'biopolitics' appears only once after the first lecture, leading many scholars to conclude that The Birth of Biopolitics abandons its projected theme (e.g. Flew, 2012: 48; M.

Gane, 2008: 355; Macey, 2009: 189; Sardinha, 2005: 99; Tribe, 2009: 682). 
Because Foucault's earlier treatment of biopolitics gave the term a negative valence, the relative absence of the term in The Birth of Biopolitics reinforces the claim made by some scholars that Foucault sympathized with neoliberalism. François Ewald, Foucault's close associate and an editor of these lectures, claims that The Birth of Biopolitics defends neoliberalism on the grounds that it promotes liberty (2012: 4, 6). Like Ewald, Michael Behrent argues that Foucault views neoliberalism as a positive improvement compared to the invasive techniques of disciplinary power (Behrent, 2009a). Following Behrent, Philip Mirowski claims that Foucault came to appreciate that 'he shared quite a bit of common ground' with his neoliberal interlocutors (Mirowski, 2013: 97). For this reason, Mirowski concludes, Foucault has little to offer those seeking to resist the neoliberal order. This complaint is developed at greater length in a volume edited by Daniel Zamora, who claims that 'Foucault is not content simply to question certain aspects of neoliberal thought, he seems to be seduced by the development of some of their central themes' (Zamora, 2014: 7; my translation).

I will argue that this reading of Foucault is misguided, but I do not think it is self-evidently false. Because Foucault's normative attitude in The Birth of Biopolitics is difficult to detect (see Brown, 2015: 55), it is understandable that a wide range of scholars are convinced that Foucault was attracted to neoliberalism (e.g. Deuber-Mankowsky, 2008: 157; Dilts, 2011: 132; de Lagasnerie, 2013; Maxwell, 2014: 161; Miller, 1993: 315). Although others have argued that The Birth of Biopolitics offers resources with which neoliberalism may be resisted (e.g. N. Gane, 2014; Nealon, 2008; Vatter, 2014), the neoliberal reading of Foucault remains influential. For this reason, I aim to rebut its main claims by examining Foucault's engagement with the economist Gary Becker. I argue that, although Becker's approach does not require the invasive normalization characteristic of disciplinary power, it entails a second form of normalization that Foucault associates with statistics. Insofar as normalization of this kind allows individuals to be governed indirectly, Becker exemplifies the regime of power that Foucault calls 'biopolitics.' Identifying the link between neoliberalism and biopolitics undermines Becker's claim to preserve individual freedom, and it indicates more broadly that The Birth of Biopolitics constitutes a circumspect critique of neoliberalism. ${ }^{2}$

In my reading, Foucault shows that neoliberal economics allows behavior to be governed with a light touch, by manipulating the range of choices available. Whereas neoliberal theorists like 
Becker claim to preserve individual liberty, Foucault argues that freedom functions as the means by which individuals are governed, the counterpart of power rather than its limit. In fact, this corresponds precisely to biopolitics as Foucault describes it. Where others denounce biopolitics by associating it with genocidal violence (see Agamben, 1998: 181), Foucault's critique is measured. Although The Birth of Biopolitics course does not condemn neoliberalism, Foucault's circumspect account of neoliberal economic theory exemplifies philosophical critique, as he understands it: it traces the contingency of neoliberal biopolitics in order to open a space for concrete acts of resistance.

\section{- Economy -}

After discussing German ordoliberalism and its classical forebears, The Birth of Biopolitics turns to Becker, who Foucault calls 'the most radical, if you like, of the American neoliberals' (2004: 273). ${ }^{3}$ Foucault observes that, where earlier economists argued that society ought to counteract the market's negative effects, Becker claims that society itself operates according to market processes (Foucault, 2004: 248). Becker argues that behaviors apparently motivated by love, dependence, and aesthetic taste can be explained economically. This allows him to subject an astonishing array of behaviors to economic analysis - including addiction, altruism, and fads in the popularity of restaurants (Becker, 1992, 1976a, 1991 respectively). ${ }^{4}$ In his view, it is possible to economically measure the choice of whether and whom to marry (Becker, 1973) and even the experience of romantic affection itself; as he puts it, 'Caring can strikingly modify the market allocation between married persons' (1974a: 14). Becker's economic approach can thus explain phenomena as diverse as the likelihood of divorce, patterns in the incidence of polygyny, and the persistence of income inequality across generations (Becker, 1974a: 24). With Becker, the domain of economic analysis expands dramatically.

The benefits of Becker's approach are especially evident in his treatment of crime, which Foucault discusses at length. Becker writes, 'Entry into illegal activities can be explained by the same model of choice that economists use to explain entry into legal activities' (1968: 207). According to Becker, the criminal weighs the benefits of crime against the potential consequences; in more technical terms, 'A person commits an offense if the expected utility to him exceeds the 
utility he could get by using his time and other resources at other activities' (1968: 176). But if criminal behavior responds consistently to environmental factors, it becomes possible to reduce the level of criminality by altering the variables that contribute to the calculations of a potential offender. In order to decrease the incidence of a particular crime, it is enough to increase the penalty or devote further resources to enforcement. As the cost and likelihood of being caught increases, crime will decrease in response - not entirely, but to a tolerable level (Becker, 1968: 176). Because the cost of discovering the crime and punishing the criminal may sometimes outweigh the benefit resulting from deterrence, Becker suggests that there is a point at which offenses ought to be tolerated (1968: 170).

In Foucault's analysis, where nineteenth century theorists posited a distinctive criminal identity (homo criminalis), Becker construes the criminal as an ordinary economic actor (homo oeconomicus) (Foucault, 2004: 259). Foucault writes in 1973, 'Disciplinary power is individualizing because it fastens the subject-function to the somatic singularity by means of a system of supervision-writing...[which] establishes the norm as the principle of division and normalization, as the universal prescription for all individuals constituted in this way' (2006: 55). This dense sentence exemplifies the way in which, for Foucault, discipline is concerned neither with the crime in question nor with criminality as such but with the individual criminal, whose identity is defined by delinquency. In contrast, because Becker argues that all human behavior involves the cool-headed calculation of benefits and costs (Becker, 1976b: 14), there is no need to identify particular individuals as deviant, nor to demand that individual behavior must conform to a predetermined norm. Where disciplinary regimes attempt to refashion individual subjects, the economic approach intervenes indirectly.

Against this background, Becker's approach might appear to be an improvement. Becker himself comments, 'It's hard for me to see something in [The Birth of Biopolitics] that Foucault doesn't like in terms of my work' (Becker et al., 2013: 7), and it is true that Foucault does not openly condemn neoliberalism. Foucault comments that Becker's approach entails 'tolerance towards minority individuals and practices, ... in which intervention comes not through the internal subjection of individuals but an intervention of the environmental type' (2004: 265). In light of statements like this, Michael Behrent argues that Foucault considered neoliberal economics to be 
an appealing alternative to disciplinary power (Behrent, 2009a: 546, see Behrent 2013: 90).

Behrent claims that, according to Foucault, 'Neoliberalism of the Chicago variety is [in Foucault's words] "much less bureaucratic," and "much less disciplinary" (disciplinariste) - which, coming from Foucault, was no mean compliment' (2009a: 566). I will return to this argument below, but at this point it is worth noting that, because Foucault's description of disciplinary regimes is openly negative (see Foucault, 1995: 308), Becker's shift away from the disciplinary approach to crime could seem consonant with Foucault's own commitments.

\section{- Normalization -}

Foucault writes that Becker displaces 'an exhaustively disciplinary society' in favor of 'a society in which the mechanism of general normalization and the exclusion of the non-normalisable' are no longer needed (2004: 265). Read in isolation, this might seem to indicate Foucault's approval; however, in context it is clear that Becker's approach exemplifies a normalizing power that operates through inclusion. In the lectures that directly precede The Birth of Biopolitics Foucault distinguishes between two kinds of normalization. He writes, 'Disciplinary normalization consists first of all in positing a model..., and the operation of disciplinary normalization consists in trying to get people, movements, and actions to conform to this model' (2007: 57). This form of normalization distinguishes between what is normal and abnormal by applying a predetermined norm, and it attempts to bring the individuals it targets into line with the norm by applying disciplinary techniques. Foucault immediately adds, 'Due to the primacy of the norm in relation to the normal...I would rather say that what is involved in disciplinary techniques is a normation rather than normalization' (2007: 57). As the example of criminality makes clear, Becker has no need to assert a norm of this kind; in Foucault's terminology here, it is normation that Becker avoids.

Whereas normation is associated with medicine (and psychiatry in particular), Foucault describes a second form of normalization that is the special province of economics. In contrast to normation, which judges behavior to be normal or not according to a predetermined norm, normalization (strictly speaking) 'starts from the normal and makes use of certain distributions considered to be, if you like, more normal than the others, or at any rate more favorable than the others. These distributions will serve as the norm' (2007: 63). In place of disciplinary attention to 
individuals, here the norm is determined through the statistical analysis of a given population, 'a plotting of the normal and the abnormal, of different curves of normality' (2007: 63). In normalization proper, the norm emerges from normal patterns through the methods of economics. As it happens, Becker's method corresponds to normalization in this sense: although Becker no longer requires 'the exclusion of the non-normalisable,' as Foucault says (2004: 265), this is simply because the economic approach can absorb deviation.

Becker's claim that every aspect of human behavior is rational concerns patterns of behavior across a population; it is not intended to hold in every individual case. Becker writes, 'Undue concentration at the individual level can easily lead to an overestimate of the degree of irrationality at the market level' (1962: 13). As everyone knows from experience, individuals are often intemperate, and so particular cases might lead one to believe that people are generally erratic. However, in Becker's view, 'Households may be irrational and yet markets quite rational' (1962: 8). Rather than excluding the possibility of the irrational individual or asserting that such people ought to be different, Becker argues that eccentricity is irrelevant at the level of generality: 'What is simply more probable for a particular household becomes a certainty for a large number of independent ones' (1962: 6). For this reason, he says, 'While the economic approach to behavior builds on a theory of individual choice, it is not mainly concerned with individuals' (1995: 650). Which is to say, Becker extrapolates from broader trends and tendencies in order to conclude that human behavior is (normally) predictable.

Although Becker's analysis operates at the level of generality, the certainties produced by statistical normalization hold profound implications for individuals. Becker allows for the existence of irrational individuals that lie outside his extrapolated norm, and yet he argues that changes to the environment would constrain the possibilities for impulsive behavior to the extent that even the irrational would act as if it were rational. Thus, for example, although some people spend inordinate sums on twee figurines, their habits nevertheless respond rationally to change: if the price of food rises, they will spend less on bric-a-brac because there is simply less left to spend. For this reason, Becker says, 'Irrational units would often be "forced" by a change in opportunities to respond rationally' (1962: 12). Although there is a sense in which the rules discerned by Becker's 
approach are less rigid than their disciplinary analogues, the fact that he extrapolates the norm rather than imposing one simply allows for subtler forms of influence.

Rather than valorizing the tolerance of Becker's approach, Foucault observes that 'in Becker's definition...this homo oeconomicus appears precisely as one who can be maneuvered, someone who responds systematically to systematic modifications that one introduces artificially in the environment' (Foucault, 2004: 274). As Foucault recognizes, if Becker is right that all behavior conforms (in fact) to rationality, then intervention may be tremendously effective even if it does not demand conformity to a given norm (in principle). Becker writes, "'Manipulating" the experiences of others to influence their preferences may appear to be inefficient and fraught with uncertainty, but it can be the most effective way available to obtain commitment' (1993: 400). ${ }^{5}$ Although normalization of this kind need not refashion individuals by force, it nevertheless enables behavior to be governed indirectly. As I will show, this form of power corresponds to what Foucault calls 'biopolitics.'

\section{- Biopolitics -}

Foucault first mentions biopolitics in October 1974 (Foucault, 1994), but he does not elaborate its significance until 1976. That year, in the first volume of The History of Sexuality, 'biopolitics' describes the regulation and control of populations. As a complement to disciplines that center on the individual body - and in contrast to punitive sovereignty - Foucault explains that biopolitics positively fosters and sustains the life of a population through the application of technical expertise. ${ }^{6}$ He writes, 'For the first time in history, no doubt, biopolitical existence was reflected in political existence; ... part of it passed into knowledge's field of control and power's sphere of intervention' (1980: 142). Foucault argues that the emergence of biopolitical power is inseparable from the development of new forms of knowledge. Crucially for my argument, the knowledge in question is characteristic of economics. He continues, 'Another consequence of this development of bio-power was the growing importance assumed by the action of the norm...Such a power has to qualify, measure, appraise, and hierarchize, rather than display itself in its murderous splendor...; it effects distributions around the norm' (1980: 144). Although the distinction Foucault draws 
elsewhere between forms of normalization is not explicit here, it is significant that biopolitics is characterized by the form of normalization associated with statistics.

In The History of Sexuality the examples of biopolitics that Foucault provides center on 'biological processes: propagation, births and mortality, the level of health, life expectancy and longevity' (1980: 139). However, in Society Must be Defended (his Collège de France lectures from the same year) Foucault is clear that biopolitics is only obliquely related to biology. There he explains that, whereas disciplinary power rules by resolving the multitude into individual bodies each of which can be formed through surveillance, training, and so forth - this new form of power is addressed to the multitude as such (2003: 243). In keeping with his analysis in The History of Sexuality, Foucault writes that 'the theory of right basically knew only the individual and society....Disciplines, for their part, dealt with individuals and their bodies in practical terms....Biopolitics deals with the population....as a problem that is at once scientific and political' (2003: 245). As Foucault goes on to describe, biopolitics works through scientific techniques ('forecasts, statistical estimates') in order to affect collective behavior at the general level (2003: 246; see Hull, 2013: 325). Although biological phenomena constitute one object for power of this kind, in Foucault's view biopolitics is broader.

In Security, Territory, Population, his lectures two years later, Foucault writes, 'This year I would like to begin studying something that I have called, somewhat vaguely, bio-power. By this I mean...the set of mechanisms through which the basic biological features of the human species became the object of...a general strategy of power' (2007: 1). The object of this form of power is not biological life per se but rather the fact that humans comprise a species, a collective that may be analyzed using statistical techniques. As Foucault explains in the course summary, "Biopolitics...aims to treat the "population" as a set of coexisting living beings with particular biological and pathological features, and which as such falls under specific forms of knowledge and technique' (2007: 367). This response to social problems calculates probabilities within a given population - including issues of birth and health but extending to every aspect of social life. Foucault writes, 'The political problem of population begins to emerge, splitting off from the technology of "police" and in correlation with the birth of economic reflection' (2007: 366). The 
management of birth, death, and so forth serves as a convenient example of a more general form of power, which consists in the government of a population through statistical normalization.

In contrast to the sovereignty associated with the feudal state and the discipline characteristic of the administrative state, Foucault writes that 'the state of government, which essentially bears on the population and calls upon and employs economic knowledge as an instrument, would correspond to a society controlled by apparatuses of security' (2007: 110). In order to clarify the concept of security, Foucault discusses the example of criminality here as well: where sovereignty prescribes the spectacle of punishment for a given offense and discipline adds a system of surveillance and correction, Foucault writes that 'the apparatus of security inserts the phenomenon in question, namely theft, within a series of probable events' (2007: 6). Security asks, Foucault says, 'What is the average rate of criminality?... How much does this criminality cost society?...What, therefore, is the comparative cost of the theft and of its repression, and what is more worthwhile: to tolerate a bit more theft or to tolerate a bit more repression?' (2007: 4-5). The presupposition of such analysis is that the cost of crime must be balanced against the cost of enforcement - which corresponds precisely to Becker's approach as Foucault describes it in The Birth of Biopolitics the following year. For this reason, although neoliberalism is not the only form that biopolitics can take, Foucault presents it as a paradigmatic case.

Because The Birth of Biopolitics records the transcript of lectures delivered orally, its style has the uneven character of extemporaneous speech, with sudden starts and stops left intact. (For better or for worse, the English translation polishes the much rougher French text.) For this reason, it would be a mistake to conclude from the relative absence of the word 'biopolitics' that the course abandons its theme. ${ }^{7}$ When read carefully and in context, The Birth of Biopolitics clearly extends Foucault's evolving analysis of biopolitics. At the outset Foucault explains,

It seems to be that the analysis of biopolitics can only occur when one has understood the general regime of this governmental reason of which I am speaking, this general regime called the question of truth, and above all the economic truth, within governmental reason. And consequently, if one understands what is at stake in the regime that is liberalism, which opposes itself to State reason - or rather, which alters it fundamentally without, perhaps, putting its foundations into question - it is once we have understood this governmental regime called liberalism that one can, it seems to me, grasp what biopolitics is (2004: 24).

The convoluted syntax of these comments - crammed into a single French sentence - demonstrates the density of a thought that Foucault rushes to articulate as the first lecture draws to a close. All at once, Foucault links biopolitics with economic knowledge (which characterizes liberalism, of which 
neoliberalism is a species), and he suggests that the liberal claim to resist state power in favor of freedom dissimulates the fact that it remains a form of government. It is for this reason that Foucault says that liberalism alters state reason without questioning its foundations: although it shifts focus from the invasive techniques of disciplinary power, it remains a technique whereby the state may manage human behavior. In this way, neoliberalism is paradigmatically biopolitical.

\section{- Freedom -}

Foucault's treatment of biopolitics provides the context required to evaluate the claim that he was drawn to neoliberalism. Becker argues that neoliberalism offers 'a liberating point of view' (Becker et al., 2012: 11, 17, 18), and some suppose that Foucault agrees. Michael Behrent argues that Foucault saw that neoliberal economics promotes freedom by effectively limiting power. According to Behrent, Foucault realized that 'economic liberalism justifies itself on the basis of its greater efficiency: it is a practice that arises when power realises that it has an interest as power in limiting power' (Behrent, 2009a: 546). In support of his interpretation, Behrent quotes Foucault:

On the horizon of this [neoliberal analysis] we find instead the image or the idea or the theme-program of a society in which there would be optimization of systems of difference, in which the field would be left free to oscillating processes, ... and finally in which there would be an intervention that would not be of the type of the internal subjection [assujettissement] of individuals, but an intervention of the environmental type (2004: 265).

Behrent claims that in this passage 'Foucault presents neoliberalism as an almost providential alternative to the repressive disciplinary model of society' (2009a: 567). However, Foucault describes this vision of oscillating difference in the conditional mood: he does not describe it as an existing accomplishment but rather as that which 'would be.' This suggests that a society without subjection remains on the horizon, as yet unrealized. What is more, the valorization of environmental intervention is advanced by Foucault's neoliberal interlocutors, not Foucault himself. For his part, Foucault argues that the neoliberal claim to preserve human freedom is a misleading fantasy.

Because the statistical methods of biopolitics allow for the efficient management of a population, Foucault claims that the liberty allowed by neoliberalism should be taken neither as a stable quantity nor as unambiguously good. He writes, 'Liberty in the regime of liberalism is not a given, liberty is not a set region that one would have to respect...Liberalism is not that which 
accepts liberty. Liberalism is that which proposes to fabricate it at each instant' (2004: 66). Although liberal theorists (including Becker) claim to respect the preexisting freedom of individuals, Foucault suggests that this liberty is itself formed by liberalism. He writes, 'This governmental practice which is installing itself is not content to respect such-and-such liberty, to guarantee such-and-such liberty. It is a consumer of liberty...Consumer of liberty, and thus it must produce it. It must produce it, it must organize it' (2004: 65). Because individual and collective interests can potentially threaten each other, liberalism cannot simply let freedom roll along unimpeded - in Foucault's view, it must actively manage the subjectivity of its subjects. Where Behrent claims that 'modern forms of power must give ample room to freedom' (2009a: 558), Foucault writes that 'at its heart, liberalism...involves a relation of production / destruction [with] liberty' (2004: 65). Insofar as individual freedom is itself shaped by this new regime of power, Foucault undercuts the neoliberal claim to protect individual freedom from the state's encroachment.

At a symposium in 2012 François Ewald addressed Becker directly: '[Foucault] sees your work, your kind of analyses as creating the possibility to promote, to envision new kinds of liberty' (Becker et al., 2012: 6; see Ewald, 1999). Given Ewald's stature as Foucault's editor and close associate, this claim carries some weight. Ewald explains, 'The challenge is to be free from morality and from the law. And he finds, I think, the solution in the writings of the economists....You propose a theory of man, a vision of man, that is non-moral and non-juridical' (Becker et al., 2012: 5). In Ewald's view, in Becker Foucault found an alternative to the moralism and legalism of sovereignty and discipline. The next year Ewald addressed Becker again: 'You were a liberator for Foucault, a liberator from past models' (Becker et al., 2013: 3). If Foucault was only concerned about sovereign and disciplinary power, Ewald might be right. However, it is not only the 'past models' Ewald mentions that Foucault found problematic - Foucault also aimed to critique the form of power that he saw as current. As Foucault's account of biopolitics makes clear, freedom from morality and the law does not entail freedom as such, for biopolitical power works within subjectivity itself.

Foucault explicitly considers the possibility that Becker's approach favors freedom, and he responds: 'Was not homo oeconomicus already a certain type of subject who precisely entitled an art of governing modelled upon the principle of economy?' (Foucault, 2004: 275). Where Behrent and Ewald present neoliberalism as the friend of freedom, Foucault suggests that Becker's 
conception of the subject is simply the correlate of governmental power. This does not invalidate it, of course: in Foucault's view, freedom never exists undetermined, independent of any influence. However, it does undermine the neoliberal claim to preserve freedom by limiting government. Where Ewald claims that Foucault saw Becker's approach as liberating, Foucault is more ambivalent: he writes, 'If one speaks of liberalism..., this does not mean that one is passing from a government which was authoritarian...to a government which becomes more tolerant, more lax, and more supple. I did not want to say that the quantity of liberty had increased' (2004: 63-4). ${ }^{8}$ In Foucault's account, biopolitics offers liberty but only to subjects whose freedom it has formed in advance; he shows that the neoliberal claim to accommodate diversity comes at the cost of a sophisticated normalization. It is therefore incorrect to conclude with Behrent (et al) that Foucault endorsed neoliberalism (Behrent, 2009b: 17); on the contrary, Foucault's account of biopolitics undermines its key claims.

\section{- Critique -}

Although Foucault's comments on neoliberalism can seem sympathetic when read in isolation, the link between neoliberalism and biopolitics indicates that The Birth of Biopolitics constitutes a sustained critique. However, Foucault's account of critique is misunderstood in much the same way as his engagement with neoliberalism. Philip Mirowski praises Foucault for acknowledging the interventionist character of neoliberal government, but he claims that 'Foucault managed to be so very prescient with regard to everyday neoliberalism precisely because he took on board such a large amount of the neoliberal doctrine as a font of deep insight into the nature of governmentality' (2013: 97). Following Behrent, Mirowski claims that Foucault came to realize how much he had in common with neoliberal doctrine, but Mirowski goes even further. In his view, 'The market as portrayed by Foucault in his late lectures on neoliberalism is the sole legitimate site for the production of indubitable knowledge of the whole; in other words, an absent deity rendered in a manner no different from Hayek or Stigler or Friedman' (Mirowski, 2013: 98). Because this entails that any critique of the state would have to pass through the market, Mirowski concludes that Foucault is 'pretty useless' for those who wish to resist the damaging aspects of neoliberal regimes (2013: 99). 
According to Mirowski, Foucault considered the market to be 'the Archimedean point that allows a critique of autocratic state power' (2013: 97). ${ }^{9}$ However, Foucault expresses the opposite view. He writes, 'The market...constitutes a place of veridiction' (2004: 33) - which is to say, 'not a law of truth but the set of rules that, with respect to a given discourse, permit one to determine which statements can be characterized as true or false' (2004: 37). In these lectures, as elsewhere, Foucault's concern is not to discern whether a given discourse is true or false but rather to analyze the rules that determine what count as truth and falsehood in particular times and places. With respect to the market, Foucault is clear: 'Politics and economics are neither things that exist, nor errors, nor illusions, nor ideologies. They are something that does not exist and which can inscribe itself in the real within a regime of truth that divides the true and the false' (2004: 22). Far from treating the market as the insurmountable site of indubitable knowledge, The Birth of Biopolitics demonstrates that it is a contingent construct that allows for the production of a form of knowledge that is by no means the only one.

Like Mirowski, Ewald claims that Foucault identifies neoliberalism with critique; he claims that '[Becker] gave him the idea that it may be possible to make a critique of governmentality that is internal to a system' (Becker et al., 2013: 21). Ewald is right that neoliberalism is critical in one sense of the term: Becker articulates a form of analysis on the basis of which it is possible to criticize a particular response to a problem such as criminality. However, this is not critique as Foucault understands it. In The Birth of Biopolitics Foucault writes, 'The critique that I propose consists in determining under what conditions and with what effects veridiction is exercised' (2004: 37). As he goes on to explain, this is rather different from arguing that a given state of affairs - for instance, the management of madness by psychiatric power - is grounded in views that are false and therefore oppressive. Instead, Foucault continues, '[Critique] would consist in saying that the problem is to make apparent the conditions that had to be met so that one could hold...views concerning madness that could be true or false according to the rules of medicine or confession or psychology' (2004: 37-8). In Foucault's account, critique does not entail condemnation, but that is because it aims at something more fundamental than the adjudication of policy. ${ }^{10}$

Although critique of this kind does not intervene directly in politics, Foucault argues that it is politically indispensable. He writes, 'In order for analysis to have a political impact, it is necessary 
that it does not focus on the genesis of truths or the memory of errors...Recalling all the errors that doctors have been able to say about sex or madness, that does us a fat lot of good' (2004: 38). Whereas the criticism of particular errors remains within a given system of truth and falsehood, Foucault's critique demonstrates that judgments of truth are made on grounds that are themselves contingent. He explains elsewhere, 'The imperative discourse that consists in saying "strike against this and do so in this way" seems to me to be very flimsy when delivered from a teaching institution or even just on a piece of paper' (2007: 3). In Foucault's view, it not is the task of a philosopher to make prescriptions of this kind, and in any case he doubts whether such interventions are effective (see Foucault, 1998a: 115, 2008: 272). Instead, he says, 'If you want to struggle, here are some key points, here are some lines of force, here are some constrictions and blockages' (2007: 3). Rather than endorsing particular forms of resistance, Foucault provides tools by which others may make tactical interventions in particular situations.

\section{- Conclusion -}

When read in isolation, some passages in The Birth of Biopolitics could seem to suggest that Foucault was drawn to neoliberalism, but I have argued that context makes clear that Becker's approach is paradigmatically biopolitical. Becker demonstrates that the state need not enforce conformity on the individual level in order to manage a problem such as criminality; as he shows, populations may be governed indirectly, through statistical methods. Because neoliberal biopolitics forms the very freedom it claims to protect, it allows for the extension of power in the name of liberty. In itself, this does not entail that biopolitics is better or worse than sovereignty and discipline, but it does disrupt the placid inevitability that strengthens biopolitical power in its contemporary, neoliberal form. In this way, rather than endorsing neoliberalism, Foucault subjects it to critique.

In contrast to his earlier treatment of biopolitics, Foucault's tone in The Birth of Biopolitics is muted. In the first volume of The History of Sexuality he associates biopolitics and genocide (Foucault, 1980: 137); in Society Must be Defended, he repeats the link with genocide (2003: 261) and adds that 'it is at this moment that racism is inscribed as the basic mechanism of power, as it is exercised in modern States' (2003: 256). It is therefore striking that The Birth of Biopolitics explicitly 
disavows the accusation that neoliberalism is effectively racist (2004: 235). Foucault's circumspection allows some to claim that he was sympathetic to neoliberalism, but Foucault's account of critique indicates that it would be misguided to expect Foucault to issue a judgment for or against it. As Foucault understands it, critique does not consist in condemnation, nor does its power derive from hyperbole. Instead, it aims to uncover the contingency of systems of power that it is tempting to take for granted.

In Foucault's account, biopolitics works from the inside: we may feel ourselves to be free, but that freedom is already formed by the very order we might wish to resist. This suggests that denouncing neoliberalism would underestimate its subtlety. Because neoliberalism is adept at incorporating deviation from the norm, there is a danger that what seems like revolution may simply reinforce the prevailing order. Instead, Foucault aims to open a space for particular strategic interventions that constitute resistance on the local (if not the global) level. Foucault's critique of neoliberal biopolitics shows that it is both more dangerous and more susceptible to change than it might seem. Because the neoliberal regime of economic truth emerged under particular conditions, neoliberal systems of government are likewise transient. Although critique of this kind does not tell individuals what they ought to do, it provides resources that are vital for those struggling to discern what might be done. ${ }^{11}$ 


\section{- Notes -}

1 Translations from The Birth of Biopolitics are my own.

2 Others have claimed that Foucault is not a neoliberal; fewer conclude that The Birth of Biopolitics is about biopolitics after all. My contribution is novel insofar as I argue that the implicit persistence of biopolitics in these lectures clarifies the way in which Foucault's treatment of neoliberalism constitutes critique.

3 The term 'neoliberalism' is widely used in both academic and popular discourse, but it is rarely defined (see Boas and Gans-Morse, 2009). Although Foucault's usage is not perfectly consistent, he takes liberalism in its classical form to favor the freedom of the market from state intervention while its contemporary, neoliberal form recognizes that the state must actively nurture the conditions for markets to flourish (e.g. 2004: 119-25).

4 Although Foucault cites Becker's work on criminality and human capital, he also relies on secondary sources (especially Jenny, 1977; see the editors' notes at Foucault, 2004: 268 \& 269). In what follows, I extend Foucault's analysis to Becker's other writings.

5 Becker writes, 'Parents worried about old-age support may try to instill in their children feelings of guilt, obligation, duty, and filial love that indirectly, but still very effectively, can "commit" children to helping them out' (1993: 400). Compare his earlier comment: 'A "family's" utility function is the same as that of one of its members not because this member has dictatorial power over the other member but because he (or she!) cares sufficiently about all other members to transfer resources voluntarily to them' (1974b: 1079-80).

6 Although Foucault associates the techniques of sovereignty, discipline, and biopolitics with particular periods, he is clear that the earlier techniques persist in later periods (see Foucault, 2003: 249, 2007: 6).

7 Perhaps the term 'biopolitics' disappears because by this point Foucault recognizes that the form of government he had earlier described in terms of biopolitics is only tangentially related to biological life, and so other terms seem more useful - 'government,' for instance. (Thomas Lemke makes a suggestion along these lines in 2014: 63.) However, as I suggest here, it may be that the apparent shift in terminology is an accident that should be attributed to the course's improvisatory style. In any case, although Foucault's use of the term 'biopolitics' is not strictly consistent, the two courses that precede The Birth of Biopolitics identify biopolitics as a form of government that manages a population through techniques of security (and statistical analysis in particular), which corresponds (as I have argued) to neoliberalism in general and to Becker in particular.

8 Compare Foucault's comment three years later: 'I do not think that there is anything that is functionally - by its very nature - absolutely liberating. Liberty is a practice' (1984: 245).

9 In order to substantiate this reading, Mirowski immediately quotes the following line from The Birth of Biopolitics: 'Political economy, I believe this is fundamentally that which made it possible to ensure the self-limitation of governmental reason' (2004: 15). Taken by itself, this might suggest that Foucault naively accepts the claims that neoliberal economic makes for itself; however, where Mirowski takes Foucault to be speaking in his own voice, in this quotation Foucault is actually engaged in exposition.

10 Paul Patton argues that critique is not the aim of The Birth of Biopolitics; he writes, 'Because knowledge of the past can work on our experience of the present in many ways, this is a more open-ended objective than those suggested by the attempts to characterize the lectures as critique' (2013: 40). I aim to suggest that critique, in Foucault's sense of the term, is open-ended in precisely this way.

11 This clarifies Foucault's turn to the care of the self in the early eighties. Andrew Dilts claims that Foucault's later account of the care of the self is 'an ethical version of the economic entrepreneurship of the self' (Dilts, 2008: 91, 2011; see Steiner, 2008: 554). My argument suggests, contra Dilts, that the resemblance between Becker's homo oeconomicus and Foucault's care of the self is illusory. Foucault writes, 'I don't think one can find any normalization in, for instance, the Stoic ethics. The reason is, I think, that the principal aim, the principal target of this kind of ethics, was an aesthetic one' (1998b: 254). This contrasts starkly with homo oeconomicus, which is the correlate of normalizing power. In Foucault's view, 'We have to promote new forms of subjectivity through the refusal of this kind of individuality that has been imposed on us for several centuries' (2000: 336) - which includes Becker's economic subject. Georges Canguilhem is therefore correct: 'It was normal, in the properly axiological sense, that Foucault would undertake the elaboration of an ethics. In the face of normalization and against it, Le Souci de soi' (1997: 32). 


\section{- References -}

Agamben, G. (1998) Homo Sacer: Sovereign Power and Bare Life, (D. Heller-Roazen, trans.). Stanford, Calif.: Stanford University Press.

Becker, G.S. (1962) 'Irrational Behavior and Economic Theory', The Journal of Political Economy 70(1): 113.

Becker, G.S. (1968) 'Crime and Punishment: An Economic Approach', Journal of Political Economy 76(2): 169.

Becker, G.S. (1973) 'A Theory of Marriage: Part I', Journal of Political Economy 81(4): 813.

Becker, G.S. (1974a) 'A Theory of Marriage: Part II', Journal of Political Economy 82(2): 11.

Becker, G.S. (1974b) 'A Theory of Social Interactions', Journal of Political Economy 82(6): 1063-93.

Becker, G.S. (1976a) 'Altruism, Egoism, and Genetic Fitness: Economics and Sociobiology', Journal of Economic Literature 14(3): 817-26.

Becker, G.S. (1976b) The Economic Approach to Human Behavior. Chicago: University of Chicago Press.

Becker, G.S. (1991) 'A Note on Restaurant Pricing and Other Examples of Social Influences on Price', Journal of Political Economy 99(5): 1109-16.

Becker, G.S. (1992) 'Habits, Addictions, and Traditions', Kyklos 45(3): 327-45.

Becker, G.S. (1993) 'Nobel Lecture: The Economic Way of Looking at Behavior', Journal of Political Economy 101(3): 385-409.

Becker, G.S. (1995) 'Nobel Lecture: The Economic Way of Looking at Behavior', pp. 633-58 in Febrero, R. and Schwartz, P. (eds), The Essence of Becker. Stanford, Calif.: Hoover Institution Press.

Becker, G.S. et al. (2012, September 5) "'Becker on Ewald on Foucault on Becker": American Neoliberalism and Michel Foucault's 1979 "Birth of Biopolitics" Lectures'.

Becker, G.S. et al. (2013, September 6) 'Becker and Foucault on Crime and Punishment.'

Behrent, M.C. (2009a) 'Liberalism Without Humanism: Michel Foucault and the Free-Market Creed, 1976-1979', Modern Intellectual History 6(03): 539-68.

Behrent, M.C. (2009b) 'A Seventies Thing: On the Limits of Foucault's Neoliberalism Course for Understanding the Present," in and, Ed, (', pp. 16-29 in Binkley, S. and Capetillo, J. (eds), A Foucault for the 21st Century: Governmentality, Biopolitics and Discipline in the New Millennium. Newcastle upon Tyne: Cambridge Scholars Publishing.

Behrent, M.C. (2013) 'Foucault and Technology', History and Technology 29(1): 54-104.

Boas, T.C. and J. Gans-Morse (2009) 'Neoliberalism: From New Liberal Philosophy to Anti-Liberal Slogan', Studies in Comparative International Development 44(2): 137-61.

Brown, W. (2015) Undoing the Demos: Neoliberalism's Stealth Revolution.

Canguilhem, G. (1997) 'On Histoire de La Folie as an Event', pp. 28-32 in Davidson, A.I. (ed.), Foucault and His Interlocutors. Chicago: University of Chicago Press.

Deuber-Mankowsky, A. (2008) 'Nothing Is Political, Everything Can Be Politicized: On the Concept of the Political in Michel Foucault and Carl Schmitt', Telos 2008(142): 135-61.

Dilts, A. (2008) 'Michael Foucault Meets Gary Becker: Criminality beyond Discipline and Punish', Carceral Notebooks 4: 77-11.

Dilts, A. (2011) 'From "Entrepreneur of the Self" to "Care of the Self": Neo-Liberal Governmentality and Foucault's Ethics', Foucault Studies 12: 130-46.

Ewald, F. (1999) 'Foucault and the Contemporary Scene', Philosophy \& Social Criticism 25(3): 81-91.

Flew, T. (2012) 'Michel Foucault's the Birth of Biopolitics and Contemporary Neo-Liberalism Debates', Thesis Eleven 108(1): 44-65.

Foucault, M. (1980) The History of Sexuality (Vol. 1). New York: Vintage Books.

Foucault, M. (1984) 'Space, Knowledge, and Power', pp. 239-56 in Rabinow, P. (ed.), The Foucault Reader. New York: Pantheon Books.

Foucault, M. (1994) 'La Naissance de La Médicine Sociale', pp. 208-28 in Defert, D. and Ewald, F. (eds), Dits et écrits III. Paris: Gallimard/Seuil.

Foucault, M. (1995) Discipline and Punish: The Birth of the Prison. New York: Vintage Books. 
Foucault, M. (1998a) 'Polemics, Politics, and Problematizations', pp. 111-9 in Rabinow, P. (ed.), Ethics: Subjectivity and Truth, Essential Works of Foucault, 1954-1984, Vol. 1 (1 edition., Vol. 1). New York: The New Press.

Foucault, M. (1998b) 'On the Genealogy of Ethics', pp. 253-80 in Rabinow, P. (ed.), Ethics: Subjectivity and Truth, Essential Works of Foucault, 1954-1984, Vol. 1 (1 edition., Vol. 1). New York: The New Press.

Foucault, M. (2000) 'The Subject and Power', pp. 326-48 in Faubion, J.D. (ed.), Power. New York: New Press.

Foucault, M. (2003) Society Must Be Defended. New York: Picador.

Foucault, M. (2004) Naissance de la biopolitique: cours au Collège de France (1978-1979). Paris: Gallimard: Seuil.

Foucault, M. (2006) Psychiatric Power: Lectures at the Collège De France, 1973-74, (G. Burchell, trans.). Basingstoke, Hampshire [England]; New York: Palgrave Macmillan.

Foucault, M. (2007) Security, Territory, Population. Basingstoke: Palgrave Macmillan.

Foucault, M. (2008) Le gouvernement de soi et des autres. Paris: Seuil/Gallimard.

Gane, M. (2008) 'Foucault on Governmentality and Liberalism', Theory, Culture \& Society 25(7-8): 35363.

Gane, N. (2014) 'The Emergence of Neoliberalism: Thinking Through and Beyond Michel Foucault's Lectures on Biopolitics', Theory, Culture \& Society 31(4): 3-27.

Hull, G. (2013) 'Biopolitics Is Not (Primarily) About Life: On Biopolitics, Neoliberalism, and Families', The Journal of Speculative Philosophy 27(3): 322-35.

Jenny, F. (1977) 'La theorie economique du crime: une revue de la litterature', pp. 296-324 in Rosa, J.J. and Aftalion, F. (eds), L'économique Retrouvée: Vieilles Critiques Et Nouvelles Analyses. Paris: Économica.

de Lagasnerie, G. (2013) 'Néolibéralisme, théorie politique et pensée critique', Raisons politiques 52(4): 63-76.

Lemke, T. (2014) 'The Risks of Security: Liberalism, Biopolitics, and Fear', pp. 59-74 in Lemm, V. and Vatter, M. (eds), The Government of Life: Foucault, Biopolitics, and Neoliberalism. New York: Fordham University Press.

Macey, D. (2009) 'Rethinking Biopolitics, Race and Power in the Wake of Foucault', Theory, Culture \& Society 26(6): 186-205.

Maxwell, J. (2014) 'Killing Yourself to Live: Foucault, Neoliberalism, and the Autoimmunity Paradigm', Cultural Critique 88: 160-86.

Miller, J. (1993) The Passion of Michel Foucault. New York: Simon \& Schuster.

Mirowski, P. (2013) Never Let a Serious Crisis Go to Waste: How Neoliberalism Survived the Financial Meltdown. London: Verso.

Nealon, J.T. (2008) Foucault Beyond Foucault: Power and Its Intensifications Since 1984. Stanford, Calif.: Stanford University Press.

Patton, P. (2013) 'Foucault's "Critique" of Neoliberalism, Rawls and the Genealogy of Public Reason', New Formations 80-81: 39-51.

Sardinha, D. (2005) 'La découverte de la liberté', Labyrinthe(22): 89-99.

Steiner, P. (2008) 'Foucault, Weber et L'histoire Du Sujet économique', Dialogue 47(3-4): 537-64.

Tribe, K. (2009) 'The Political Economy of Modernity: Foucault's Collège De France Lectures of 1978 and 1979', Economy and Society 38(4): 679-98.

Vatter, M. (2014) 'Foucault and Hayek: Republican Law and Liberal Civil Society', pp. 163-84 in Lemm, V. and Vatter, M. (eds), The Government of Life: Foucault, Biopolitics, and Neoliberalism. New York: Fordham University Press.

Zamora, D. (2014) 'Introduction: Foucault, la gauche et les années 1980', pp. 5-11 in Zamora, D. (ed.), Critiquer Foucault: les années 1980 et la tentation néolibérale. Bruxelles: Aden. 
David Newheiser is a Postdoctoral Research Fellow in the Institute for Religion \& Critical Inquiry at the Australian Catholic University. His research focuses on the topics of power and biopolitics, secularization, and the history of sexuality. He has published articles on interpretation, apocalypticism, love, secularity, and sexuality, and he is currently completing a book on the relation between temporal transcendence and discursive negativity in Dionysius the Areopagite and Jacques Derrida. 